\title{
ЗАБЕЗПЕЧЕННЯ ПРОСТОРОВОЇ СТІЙКОСТІ ПРИ РЕКОНСТРУКЦІЇ ЖИТЛОВИХ БУДИНКІВ МИНУЛИХ РОКІВ ЗАБУДОВИ
}

ОБЕСПЕЧЕНИЕ ПРОСТРАНСТВЕННОЙ УСТОЙЧИВОСТИ ПРИ
РЕКОНСТРУКЦИИ ЖИЛЫХ ЗДАНИЙ ПРОШЛЫХ ЛЕТ ЗАСТРОЙКИ

PROVIDING SPACE STABILITY FOR RECONSTRUCTION RESIDENTIAL BUILDINGS OF MIND YEARS INSURANCE

Клименко Є.В., д.т.Н., проф., Гілодо О.Ю., к.т.н., доц., Арсірій А.М., к.т.н., доц. (Одеська державна академія будівництва та архітектури, м. Одеса)

Клименко Е.В., д.т.Н., проф., Гилодо А.Ю., к.т.Н., доц., Арсирий А.Н., к.т.н., доц. (Одесская государственная академия строительства и архитектуры, г. Одесса)

Klymenko Ie.V., ScD, Prof., Gilodo A.Y., Ph.D., Assistant Prof. Arsiriy A.N., Ph.D., Assistant Prof. (Odessa State Academy of Civil Engineering and Architecture, Odessa)

В історичному центрі Одеси. реалізована реконструкція триповерхової будівлі старовинної забудови. Технічний стан окремих несучих конструкцій був визначений в діапазоні від непридатного до нормальної експлуатації до аварійного. Наведені практичні методи підсилення будівельних конструкцій і відновлення просторової стійкості будівлі.

В историческом центре Одессы. реализованная реконструкция трехэтажного здания старинной застройки. Техническое состояние отдельных несущих конструкций было определено в диапазоне от непригодного к нормальной эксплуатации до аварийного. Приведены практические методы усиления строительных конструкций и возобновление пространственной стойкости здания.

In the historical center of Odessa, the reconstruction of a three-story building of ancient building was implemented. The technical condition of the bearing structures was defined in the range from unsuitable to normal operation to emergency. The main reasons have become a long period of operation without the necessary current and major repairs and accident of water-borne communications in the basement, which led to uneven subsidence of foundations. Additional factors - long-term leakage from water-borne 
networks, damage to the drainage and drainpipes. The spatial stability and stiffness of the building were lost due to the formation of through cracks in the walls, dividing the building into separate blocks. During the reconstruction a complex of works was carried out that included: reducing loads on the walls and overlays by replacing mortars from ground limestone with ephetinal sound-insulation, reinforcing and replacing wooden beams of over lapping with rolling channels, merging longitudinal and transverse walls with reinforcement of steel strainers from tension devices in the level of ceilings of the first and third floors, installation of vertical steel welded frames diaphragms from rolling profiles in places demounted stone partitions.

\section{Ключові слова:}

Обстеження, підсилення, просторова стійкість.

Обследования, усиление, пространственная устойчивость.

Inspection, amplification, spatial stability.

Вступ. Просторова жорсткість конструкції забезпечується при іiї геометричній незмінності в трьох площинах - двох вертикальних і одній горизонтальній. Складові елементи конструкції під впливом навантажень можуть локально змінити свою форму, але тільки в межах, окреслених нормами і тільки на час дії навантаження. Більшість аварій трапляється, насамперед, коли просторова стійкість елемента, або всієї конструкції втрачається. Для сучасних багатоповерхових будинків з залізобетону або сталі в каркасному чи безкаркасному вигляді розроблені типові надійні конструктивні рішення, що гарантують просторову жорсткість усієї будівлі. Але задача вкрай ускладнюється коли мова йде про реконструкцію житлових будинків побудованих більше ніж сто років тому і виконаних зі штучних матеріалів. Для міста Одеси, як правило, це вапняк-черепашник. Додатковими чинниками служать десятиліття поганої експлуатації і бажання новітніх володарів житлової нерухомості пристосувати іiі до іншого призначення з розкриттям прорізів і демонтажем значних ділянок несучих стін тощо. При цьому проектувальникові необхідно забезпечити несучу здатність будівлі при відсутності конкретних нормативних рекомендацій, тому що кожна реконструкція це окремий випадок, окрема унікальна технічна ситуація.

В'язі в безкаркасних житлових будинках зі стінами із штучних матеріалів таких як цегла або камінь вапняк-черепашник, як окрема конструкція, не існують. Просторова стійкість головних вертикальних конструкцій - стін та будівлі в цілому забезпечується їх сумісною роботою 3 перекриттями у вигляді, в більшості випадків для старовинної забудови, дерев'яних балок і типового дерев'яного настилу з дощок та засипкою будівельним сміттям чи молотим вапняком. З'єднання усіх конструктивних елементів - шарнірні, що добре впливає на сприйняття сейсмічного навантаження. 
В історичному центрі Одеси реалізована реконструкція триповерхової житлової будівлі. Технічне завдання містило, насамперед, збереження будинку, який мав пошкодження у вигляді наскрізних тріщин в зовнішніх стінах, і розробку конструктивного рішення, що забезпечує можливість демонтажу несучих вертикальних елементів. Методом вирішення цієї складної задачі став аналіз подібних об'єктів і багатолітній досвід обстеження і проектування.

Аналіз останніх досліджень. Питанню підсилення будівельних конструкцій, як невід'ємному елементу реконструкції, завжди приділялось достатньо уваги з боку дослідників будівельних конструкцій. Відомі роботи М. Н. Лащенко [1], Е. В. Горохова [2], М. М. Михеєва [3] та інших. Методику підвищення довговічності розробляли М. Н. Сахновський [4], Г. А. Поривай [5], М. Д. Бойко [6]. Реконструкції різноманітних об'єктів присвячені роботи В. К. Соколова [7], В.Н.Кутукова[8], М. С. Шумілова [9]. Але є особлива галузь реконструкції - це реконструкція пам'яток будівництва та архітектури або знакових для міста будівель, де треба враховувати особливості реставрації. В першу чергу це стосується фасадів, тому що за довгі роки експлуатації пройшло чимало змін об'ємно-планувальних рішень, тобто втрати всередині будинку дуже значні і головне - це збереження зовнішнього вигляду історичної будівлі. В першу чергу потрібно вирішити в якому вигляді повинен предстати будинок після реконструкції з реставрацією. Досвід обстеження споруд, побудованих на початку 19 століття свідчить, що в більшості випадків справа йде про комплекс технічних проблем, де потрібно забезпечити несучу здатність будинку і виконати значний об'єм підсилювання несучих конструкцій і при цьому максимально зберегти архітектурний аутентичний декор фасадів і дуже дбайливо поставитись до всього, що збереглось в первозданному вигляді. Досліджень на цю тему не дуже багато. Значними можна вважати роботи В. Т. Гроздова [10] i Ю. М. Іванова [11].

Об'єкт дослідження - триповерхова будівля № 436 з підвалом i горищем, що не експлуатується по вулиці Троїцькій в місті Одесі. Побудована в 1901-03 pp. архітектором А. Р. Рейхенбергом. На час обстеження в будинку частково були розташовані житлові квартири і офіси, значна частина другого і третього поверхів не експлуатувалась. В кінці 90-х років 20 століття внаслідок аварії котельній, розташованій в підвалі, стався порив водонесних комунікацій і підтоплення стрічкових фундаментів 3 вапняка-черепашника, що призвело до нерівномірних осідань основ і значних тріщин в несучих стінах по всій висоті будівлі.

Мета дослідження. Визначити і зафіксувати технічний стан основних несучих та огороджуючих будівельних конструкцій будинку, дати рекомендації щодо можливості і умов його нормальної експлуатації 3 розробленням конструктивних рішень забезпечення просторової стійкості. 
Методи дослідження. Обстеження здійснювали на підставі технічного завдання і складалось воно з наступних етапів:

- попередній візуальний огляд з метою знайомства 3 об'єктом, виявлення аварійних ділянок, визначення умов експлуатації; складання програми обстеження з обов'язковими заходами з техніки безпеки при виконанні робіт;

- геологічні вишукування для визначення властивостей грунтів основи 3 бурінням свердловин, розробки шурфів і лабораторним дослідженням грунтів. До цього етапу слід віднести визначення розрахункового опору грунту на підставі визначення властивостей грунтів;

- обмірювання конструкцій з розробкою відповідних креслень планів поверхів і розрізів, фасадів;

- детальний огляд конструкцій з визначенням ступеня фізичного зносу, дефектів, пошкоджень, складанням дефектних відомостей;

- аналіз чинників пошкоджень i дефектів i роботи 3 розкриттям перекриттів, горища, опорних вузлів балок тощо;

- визначення навантажень, дійсної розрахункової схеми будівлі i iï окремих конструкцій, визначення можливості сумісної просторової роботи конструкцій i будинку в цілому за наявності визначених дефектів i пошкоджень;

- перевірочні розрахунки конструкцій, вузлів, стиків, з'єднань 3 урахуванням реальних розрахункових схем и технічного стану;

- розробка висновку про технічний стан будинку i рекомендацій 3 нормальної експлуатації з кресленнями підсилень конструкцій і будинку в цілому.

Результати досліджень. В 1998 році, внаслідок аварії в елеваторному вузлі стався залив основ фундаментів та їх нерівномірне осідання. Максимальні пошкодження у вигляді вертикальних тріщин отримали дві зовнішні і одна внутрішня несучі повздовжні та поперечні стіни. Додатково повздовжня внутрішня стіна була ослаблена непрацюючими вентиляційними каналами, що розрізали іiі на окремі блоки. Поперечні перегородки, які складалися із заплечиків шириною 600 мм біля зовнішньої стіни, закладених прорізів та печей суттєвої жорсткості не мали. Надвіконні перемички в зовнішніх стінах були пошкоджені вертикальними тріщинами. Вертикальні тріщини в зовнішніх стінах мали ширину розкриття до 30 мм в рівні третього поверху і горища, що свідчить про відрив лівоворотнього флігелю будинку від центрального. Різні відмітки перекриття другого поверху в різних приміщеннях знизили його просторову жорсткість. Несучі дерев'яні балки міжповерхових перекриттів вражені гниллю, мали недопустимі прогини, окремі балки знаходилися в аварійному технічному стані. Несучі дерев'яні конструкції кроквяної системи даху, вузли елементів послаблені, стійки і кроквяні ноги розсохлися. Покрівля з азбестоцементних хвилястих листів пошкоджена тріщинами і зколами, примикання азбестоцементних листів до виступаючих елементів даху порушені. Жолоби, пелена, водостічні воронки і 
труби пошкоджені, дощова вода заливала карниз, що приводило до обвалення елементів карнизу, ліпного декору фасадів, штукатурного покриття зовнішніх стін та огорожі балконів.

Технічний стан фундаментів визначали шляхом виконання шурфів біля несучих стін. За результатами обстеження фундаменти знаходились у задовільному технічному стані, тріщини, що багато років тому стабілізувались, свідчили про нерівномірні осідання грунтів в кінці 90-х років. У стінах та перегородках зафіксовані похилі та вертикальні тріщини, їх загальний технічний стан визначений, як непридатний до нормальної експлуатації. Міжповерхові перекриття мали недопустимі прогини, хисткість, технічний стан - непридатний до нормальної експлуатації. Окремі балки перекриттів другого і третього поверхів знаходилися в аварійному технічному стані. На даху виявили розшарування деревини кроквяних ніг, враження гниллю мауерлата, кінців крокв, ослаблення врубок і з'єднань. Просторова стійкість і жорсткість кроквяної системи знижена. Покрівля 3 азбестоцементних хвилястих листів мала тріщини, сколи, відсутні окремі листи. Фізичний стан даху i покрівлі - непридатний до нормальної експлуатації.

На підставі проведеного аналізу технічного стану і фізичного зносу обстежених несучих та огороджувальних конструкцій встановлено наступне. Характер, напрямки і ширина розкриття тріщин в стінах, пошкодження міжповерхових перекриттів і даху свідчило про те, що головними чинниками їх наявності було:

- довгий період експлуатації без проведення необхідних поточних i капітальних ремонтів;

- впливи техногенного характеру: аварія водонесних комунікацій в підвалі, що стало причиною нерівномірного просідання фундаментів, багаторічні витоки 3 водонесних мереж, пошкодження вимощення, водостічних труб.

Для забезпечення нормальної експлуатаційної придатності будинку запропоновано і реалізовано при реконструкції комплекс робіт що включає:

- зниження навантажень на стіни і перекриття;

- очистку перекриттів від засипки з молотого вапняку і будівельного сміття і заміну ії на ефективну звуко-теплоізоляцію;

- підсилення дерев'яних балок перекриття першого поверху прокатними швелерами;

- демонтаж перекриттів другого і третього поверхів і заміну на перекриття 3 несучими балками з прокатних двотаврів і дерев'яним настилом з дощок;

- демонтаж несучих і огороджувальних конструкцій даху і заміну на кроквяну систему з прокатних профілів і покрівлею з металочерепиці;

- забивання тріщин в кам'яних стінах шириною розкриття до 10 мм спеціальним розчином; 
- підсилення віконних і дверних прорізів з тріщинами в перемичках сталевими зварними обіймами з прокатних кутиків на планках;

- підсилення надвіконних перемичок 3 кам'яної кладки 3 тріщинами шириною розкриття більше ніж 5 мм сталевими зварними обоймами 3 прокатних швелерів на планках;

- підсилення стін на ділянках з тріщинами шириною розкриття більше ніж 10 мм, закладкою ніш та перекладкою кладки з забезпеченням зв'язків між новою цегляною i старою кам'яною кладкою арматурними сітками i анкеруючими стержнями, або цегляними замками і цегляними замками 3 якорями з прокатних швелерів;

- демонтаж конструкцій балконів з їх поновленням з несучими балками 3 прокатних двотаврів і залізобетонним настилом.

Окремо слід виділити заходи щодо забезпечення просторової стійкості і жорсткості всієї будівлі, порізаної наскрізними тріщинами на окремі блоки:

- об'єднання повздовжніх і поперечних стін шляхом підсилення сталевими напруженими тяжами з натяжними пристроями в рівні перекриттів першого $\mathrm{i}$ третього поверхів. Відстань між тяжами приймали 4-6 м, щоб на один тяж припадала площа стіни не більше ніж $20 \mathrm{~m}^{2}$ (рис.1);

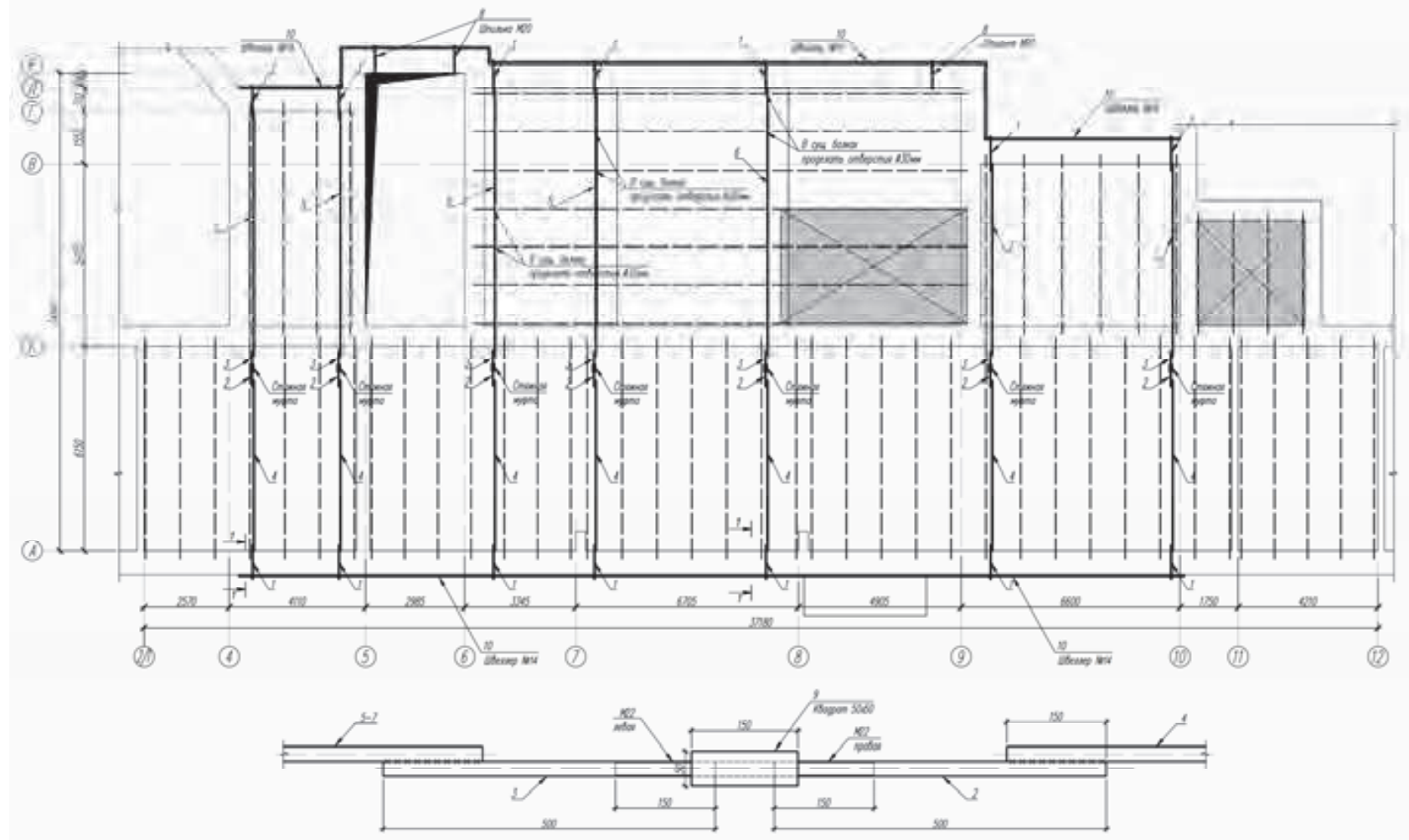

Рис. 1. Схема влаштування тяжів в площі перекриттів

- влаштування вертикальних сталевих зварних рам - діафрагм з прокатних профілів в місцях демонтованих кам'яних перегородок (рис.2). 


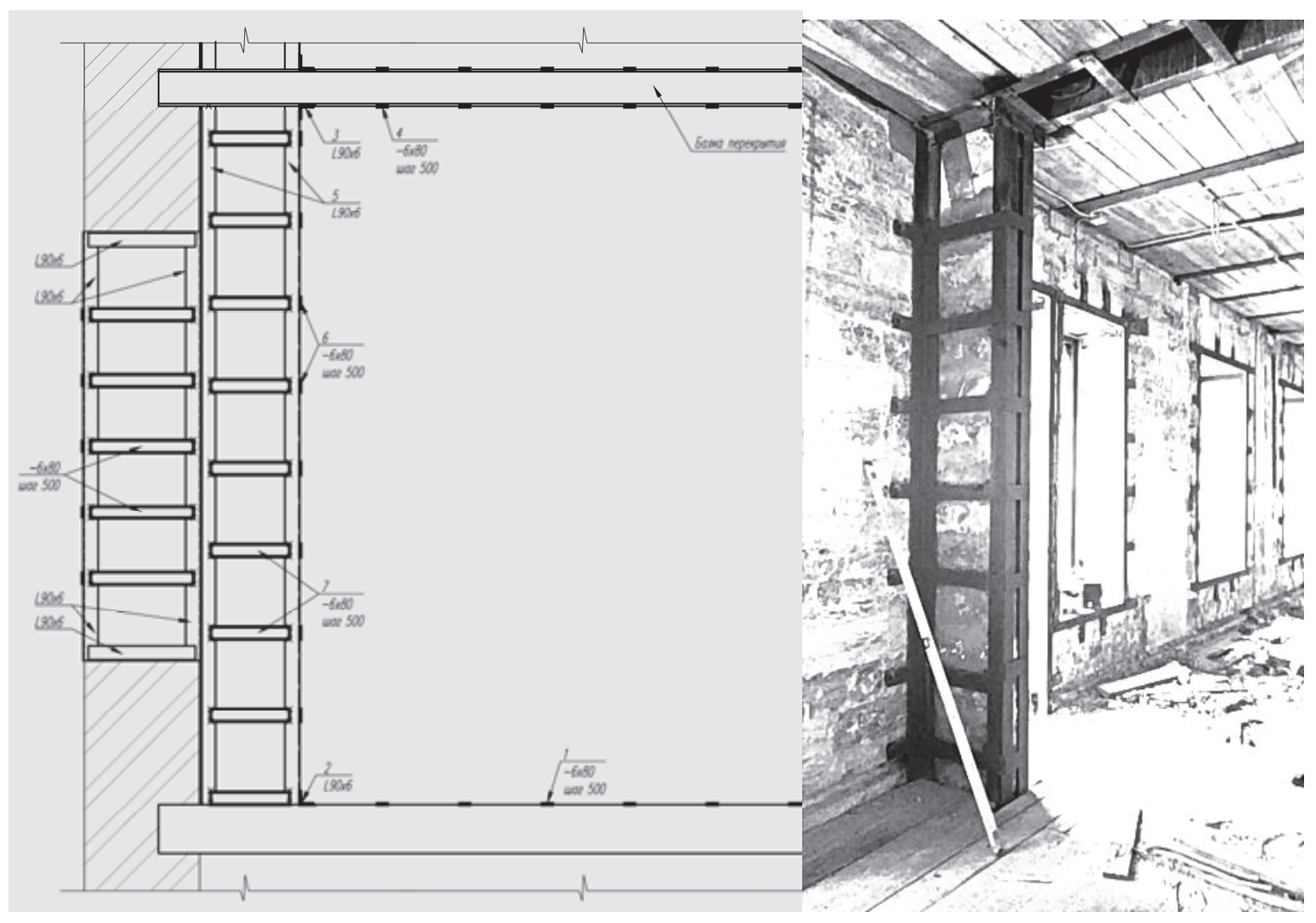

Рис. 2. Конструкція вертикальних сталевих зварних рам - діафрагм

Висновки. Характер, напрямки і ширина розкриття тріщин в стінах, пошкодження міжповерхових перекриттів i даху свідчать про те, що головними причинами їх наявності є:

- тривалий період експлуатації будинку без проведення необхідних поточних і капітальних ремонтів несучих і огороджувальних конструкцій;

- впливи техногенного характеру: аварія водонесних комунікацій, багаторічні витоки з водонесних мереж, пошкодження опорядження.

Забезпечення нормальної експлуатації можливо після виконання відповідних рекомендацій.

1. Лащенко М. Н. Повышение надёжности металлических конструкций зданий и сооружений при реконструкции.- Л.: Стройиздат, Ленинградское отделение, 1987. $136 \mathrm{c}$.

2. Горохов Е. В. Долговечность стальных конструкций в условиях реконструкции. - М.: Стройиздат, 1994. - 484 с.

3. Михеев И. М. Усиление конструкций промышленных зданий. -Киев: Будівельник, 1969. - 192 с.

4. Сахновський М. Н., Титов А. М. Уроки аварий стальных конструкций. - К.: Будівельник. 1969.- 200 с.

5. Порывай Г. А. Техническая эксплуатация зданий. - Стройиздат. 1990. -369 с.

6. Бойко М. Д. Диагностика повреждений и методы восстановления эксплуатационных качеств зданий. -Л.: Стройиздат, 1975. - 334 с. 
7. Соколов В. К. Основніе методы и принципы реконструкции жилых зданий. М.:1969. -232 c.

8. Кутуков В. Н. Реконструкция жилых зданий. - М.: Высш. школа, 1981. - 263 с.

9. Шепелев Н. П.Реконструкция городской застройки. - М.: Высшая школа, 2000. $-271 \mathrm{c}$.

10. Гроздов В. Т. Некоторые проблемы усиления несущих конструкций при реставрации зданий // Дефекты зданий и сооружений. Усиление строительных конструкций: Материалы IV научно-методической конференции ВИТУ. - СПб. - с.4348.

11. Иванов Ю. В. Реконструкция зданий и сооружений: усиление, восстановление и ремонт. - М.: Ассоциация строительных вузов, 2013. - 312 с.

1. Lashchenko M. N. Povysheniye nadozhnosti metallicheskikh konstruktsiy zdaniy i sooruzheniy pri rekonstruktsii.- L.: Stroyizdat, Leningradskoye otdeleniye, 1987. - 136 s.

2. Gorokhov Ye. V. Dolgovechnost' stal'nykh konstruktsiy v usloviyakh rekonstruktsii. - M.: Stroyizdat, 1994. - 484 s.

3. Mikheyev I. M. Usileniye konstruktsiy promyshlennykh zdaniy. -Kiyev: Budível'nik, 1969. - $192 \mathrm{~s}$.

4. Sakhnovs'kiy M. N., Titov A. M. Uroki avariy stal'nykh konstruktsiy. - K.: Budível'nik. 1969.- $200 \mathrm{~s}$.

5. Poryvay G. A. Tekhnicheskaya ekspluatatsiya zdaniy. - Stroyizdat. 1990. -369 s.

6. Boyko M. D. Diagnostika povrezhdeniy i metody vosstanovleniya ekspluatatsionnykh kachestv zdaniy. -L.: Stroyizdat, 1975. - 334 s.

7. Sokolov V. K. Osnovníe metody i printsipy rekonstruktsii zhilykh zdaniy. M.:1969. - $232 \mathrm{~s}$.

8. Kutukov V. N. Rekonstruktsiya zhilykh zdaniy. - M.: Vyssh. shkola, 1981. - 263 s.

9. Shepelev N. P.Rekonstruktsiya gorodskoy zastroyki. - M.: Vysshaya shkola, 2000. $271 \mathrm{~s}$.

10. Grozdov V. T. Nekotoryye problemy usileniya nesushchikh konstruktsiy pri restavratsii zdaniy // Defekty zdaniy i sooruzheniy. Usileniye stroitel'nykh konstruktsiy: Materialy ÍV nauchno-metodicheskoy konferentsii VITU. - SPb. - s.43-48.

11. Ivanov YU. V. Rekonstruktsiya zdaniy i sooruzheniy: usileniye, vosstanovleniye i remont. - M.: Assotsiatsiya stroitel'nykh vuzov, 2013. - $312 \mathrm{~s}$. 